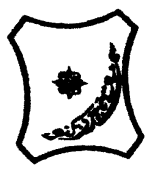

Bayero Journal of Pure and Applied Sciences, 10(1): 397 - 404

ISSN $2006-6996$

\title{
PHYTOCHEMICAL ANALYSIS AND ASSESSMENT OF BIOETHANOL PRODUCTION POTENTIAL OF CYMBOPOGON SCHOENANTHUS (CAMEL GRASS) UNDER DIFFERENT pH
}

\author{
Rabe, M. ${ }^{1}$, Aleiro, B.L. ${ }^{1}$, Maishanu, H.M. ${ }^{1}$, Galadima, A. ${ }^{2}$, Maikudi, H.M. ${ }^{3}$ and \\ Babasidi, S. L. ${ }^{1}$ \\ ${ }^{1}$ Department of Biological Science, Usman Danfodiyo University Sokoto, Sokoto state. \\ ${ }^{2}$ Department of Pure and Applied Chemistry, Federal University Gusau, Zamfara State. \\ ${ }^{3}$ Department of Biological Science, Ibrahim Badamasi Babangida University, Lapai, \\ Niger state \\ Correspondence author: amina.musa@udus.sok.edu.ng
}

\section{ABSTRACT}

In this research, the phytochemical and bioethanol content of Cymbopogon schoenanthus was assessed under three different $\mathrm{pH}$. The phytochemical screening and proximate analysis was carried out according to standard qualitative and quantitative methods. Where alkaloids, balsam, flavonoids, glycosides, saponin, carbohydrates, Protein, volatile oil, minerals etc. were analyzed. Bioethanol was produced using enzymatic hydrolysis after pretreatment under different $\mathrm{pH}$ viz: $\mathrm{pH} 6,7$ and 8 all under ambient temperature. It was then fermented using Saccharomyces cerevisiae. Each of the treatments was made in triplicates. The absorbance was determined for reducing sugar and at the end of the production it was subjected to Gas chromatography and mass spectroscopy to analyze the end product of bioethanol produced. The result for phytochemicals shows the presence of flavonoids in C. schoenanthus (13\%) followed by volatile oil (6.44\%). Alkaloids, saponin and tannins are all present. The result for proximate analysis shows highest percentage of carbohydrates $(70.69 \%)$ followed by ash (11.66\%), protein (11.14\%), fibres (2.83\%). The mineral analysis shows the presence of calcium $(1.18 \mathrm{mg} / \mathrm{L})$, magnesium $(1.02 \mathrm{mg} / \mathrm{L})$, phosphorous $(6.37 \mathrm{mg} / \mathrm{L})$, potassium $(1933.33 \mathrm{mg} / \mathrm{L})$ and sodium $(59.17 \mathrm{mg} / \mathrm{L})$. The absorbance of reducing sugar was higher at pH8 (0.0679). Same happened to the concentration of the bioethanol. The GC-MS analysis of the bioethanol produced shows the presence of Ethyl alcohol (bioethanol) in all the treatments at different $\mathrm{pH}$. However, Hydrazine carboxamide was present in all the treatments. In addition iso-butane, 1-butanol, butanoic acid and propane were found present, all having fuel potential and are good source of gasoline. These are produced as a result of fermentation and enzymatic activities of the organic compound present in the biomass sample.

Key: Bioethanol, Cymbopogon schoenanthus, $\mathrm{pH}$ and Phytochemical screening.

\section{INTRODUCTION}

The search for a sustainable and renewable source of energy is still going on to replace fossil fuel that is causing environmental problem and hazards. However, the use of Biomass for the production of biofuel too is facing a lot of challenges and debates till date. Some of these challenges are cost effective biomass, food security, water use efficiency of the biomass, land use efficiency etc. To overcome these challenges, there is need to search for substitute in order to tackle the issues. Just as Jatropha species having so many potentialities such as drought tolerance, less cost and biofuel potential same happened to Cymbopogon schoenanthus. As observed in a research conducted on the chemical content of the grass species indicated high content of octane which is a good source of fuel. 
Cymbopogon schoenanthus (L.) (camel grass or 'tsabre' grass) belong to the family Poaceae. Having ginger flavor or scent with numerous applications such as culinary, costumes, insecticidal and medicinal potentialities. It is a compact tufted perennial grass with culms $60-200 \mathrm{~cm}$ high, which grows on dry stony ground of subdesert bush land plant that can get along with minimum water. All parts of the plant are aromatic having some similar features and importance with lemon grass. Distillation of the root and leaves of camel grass yields a fragrant oil (Amina et al., 2013). This plant is found abundantly growing on marginalized lands in north western Nigeria especially within Sokoto state. The aim of this research is to assess the phytochemicals and bioethanol contents of Cymbopogon schoenanathus (camel grass). The specific objectives were to:

1. Determine the quantity of phytochemical and proximate composition present in the grass.

2. Determine the absorbance of reducing sugar at different $\mathrm{pH}$ level

3. Evaluate the effect of pretreatment and enzymatic hydrolysis in the production of bioethanol produced.

4. Analyze the presence of bioethanol after enzymatic hydrolysis using Gas chromatography mass spectroscopy.

\section{METHODOLOGY}

Study Area - The study was conducted in the Departments of Biological Sciences, department of Pure and Applied Chemistry and Biochemistry, Faculty science, Usmanu Danfodiyo University, Sokoto.

Collection of Samples -The sample of the grass was obtained from the main campus of Usmanu Danfodiyo University, Sokoto. The species was authenticated by a taxonomist at the University Herbarium, Sokoto.

Drying, Pulverization and Crushing of Grass Sample - The grass sample was air-dried under shade in the biological garden. Each sample was pulverized and sieved into a fine powder using mortar and pestle. Another sample of the grass was crushed with hammer into small sizes in order to obtain $20 \mathrm{~g}$ of the substrate for bioethanol production (Sebayang, 2016).

Phytochemical Screening and Proximate Analysis - involved the estimation of the main components of food using procedures that allow a reasonably rapid and acceptable measurement of various food fractions. In this analysis moisture content, ash, crude protein, carbohydrates, lipids and mineral content of the grass species was determine using standardized methods (Amina et al., 2013).

Pre-treatment - is one of the most important steps in order to process the material to release the fermentable sugars (maximum reducing sugars). In this study hydrothermal explosion method was applied Adagatin et al., 2015) (, where twenty (20) grams of pulverized grass (C. schoenanthus) was mashed with hammer and measured using weighing balance. It was then diluted with $300 \mathrm{~cm}^{3}$ distilled water. The suspension prepared was then autoclaved at $121^{\circ} \mathrm{C}$ for 15 minutes to sterilized and prevent the growth of other microorganisms as well as to the degradation of the complex carbohydrate (ligno-hemicellulose material) present in the plant species prior to release of sugar (Sebayang et al., 2016; Baig, 2004). Three different set of $\mathrm{pH}$ were set for the production of bioethanol viz: acidic $(\mathrm{pH} 5)$, neutral (7.00) and alkali (pH8). The $\mathrm{pH}$ of the grass samples for the first sets which was acidic were retained $(\mathrm{pH}$ of 5.0). For the remaining sets the $\mathrm{pH}$ was adjusted with 1 Mol. of Sodium Hydroxide $(\mathrm{NaOH})$ to Neutral (pH 7.0) and Alkaline $(\mathrm{pH}$ 8.0) using a pH Meter Lenway Model No 3015. All the sets were in triplicate at different $\mathrm{pH}$. Hydrolytic organism was inoculated for enzymatic hydrolysis as explained below after culturing, sub-culturing and identification of the species.

Enzymatic Hydrolysis - Saccharification of enzyme pre-treated biomass was done enzymatically to get fermentable sugars (Gupta et al., 2012; Sebayang et al., 2016). Twenty (20) grams of Aspergilus niger was used for enzymatic pre-treatment, these was transferred into $500 \mathrm{~cm}^{3}$ volumetric flask. Thereafter, the volumetric flask fitted with cotton and aluminium foil was placed in an incubator for period of seven days at room temperature $\left(36^{\circ} \mathrm{C}\right)$. It was allowed to stay for enzymatic activity to occur in order to breaks the hemi-cellulose present in the plant samples. The glucose produced after was collected and was subjected for reducing sugar test. 
Determination of Reducing Sugar Concentration - The reducing sugar content following hydrolysis of cellulose materials by enzyme was determined using the method of Gupta (2016). The reducing sugar content was determined by making reference with standard curve of known concentration for Glucose.

Fermentation - Fermentation of the substrates to simple sugars (Glucose) was carried out using activated baker yeast (Saccaromycese cerevisea) as described by Nasrullah and Touseef, (2014).

Distillation - The bioethanol produced from the fermentation process was subjected to fractional distillation (Macro kjeidhl distillation apparatus) in order to remove water and other impurities.

Qualitative and Quantitative Test for Bioethanol - Bioethanol was then tested qualitative and quantitatively using Fourier transformer and infrared spectroscopy (FT-IR) analysis. The absorbance was measured at $588 \mathrm{~nm}$ using UV-visible-1650pc, Schimadzu Spectrophotometer. Spectrophotometric graph of absorbance was plotted against concentration which is used as the standard curve.
Determination of Bioethanol using Gas Chromatography and Mass Spectroscopy Sample produced at the end of hydrolysis and fermentation activities was subjected to GCMS analysis to determine the end product. The analysis was performed using GC-MSQP2010 plus (Shimadzu, Japan) equipped with flame ionization detector (FID). The injection was conducted in split less mode at $250^{\circ} \mathrm{C}$ for 3 minutes by using an inlet of $0.75 \mathrm{~mm}$ ionization detector to minimize peak broadening.

Statistical analysis - The data obtained was subjected to analysis of variance and means that were significant were separated using $\mathrm{t}$ test at $p<0.05$. Statistical Package for Social Sciences (SPSS) version 20 was used for this analysis.

\section{RESULTS}

The results obtained from phytochemical screening of the leaf extract of Cymbopogon schoenanthus is shown in Table 1 . The results shows higher percentage of flavonoid (13\%) than alkaloids, glycosides, saponin and tannins, which are also found present in the grass samples as shown in a table 1 below.

Table 1: Quantitative test for Phytochemical present in C. schoenanthus leaf powder

\begin{tabular}{lc}
\hline Compounds & $\begin{array}{c}\text { Quantitative value } \\
\text { (\%) }\end{array}$ \\
\hline Alkaloids & 1.74 \\
Flavonoids & 13.00 \\
Glycosides & 0.55 \\
Saponins & 2.00 \\
Tannins & 1.29 \\
Volatile oil & 6.44 \\
\hline
\end{tabular}

Percentage of Proximate composition of $C$. schoenanthus - The result of proximate analysis presented in Figure 1 indicated that carbohydrate content in $C$. schoenanthus samples is much higher $(70.66 \%)$ when compared to crude protein $(11.14 \%)$, fibres $(2.83 \%)$, lipids $(3.67 \%)$, moisture $(7.17 \%)$ and ash content $(11.67 \%)$.

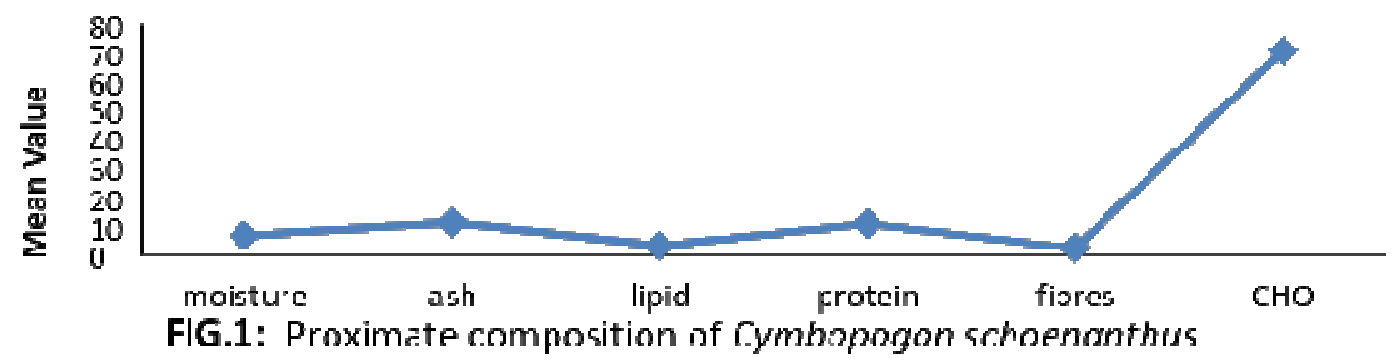


Quantitative Analysis of Mineral higher in the grass reaching up to Constituents of $C$. schoenantus - Table $21933.33 \mathrm{mg} / \mathrm{L}$. The quantity of sodium is also shows the quantity of inorganic minerals high in the samples (59.17) but the amount of present in the grass samples. The result reveals that the quantity of potassium is calcium and magnesium is lower $(1.18 \mathrm{mg} / \mathrm{L}$ and $1.02 \mathrm{mg} / \mathrm{L})$.

Table 2: Mineral Constituents in C. schoenanthus

\begin{tabular}{ll}
\hline Parameters & Amount (Mg/L) \\
\hline Calcium & 1.18 \\
Magnesium & 1.02 \\
Phosphorus & 6.37 \\
Potassium & 1933.33 \\
Sodium & 59.17 \\
\hline
\end{tabular}

Effect of pH on Bioethanol Concentration The effect of $\mathrm{pH}$ on concentration of $C$. schoenanthus (camel grass) is shown in Figure 2 below which indicated that the highest bioethanol concentration of $0.061 \mathrm{mg} / \mathrm{ml}$ in $C$. schoenanthus was observed at $\mathrm{pH}$ range 8.0 (Alkaline), followed by pH5 with $0.019 \mathrm{mg} / \mathrm{ml}$. $\mathrm{pH} 7$ has the least concentration of $0.0088 \mathrm{mg} / \mathrm{ml}$.

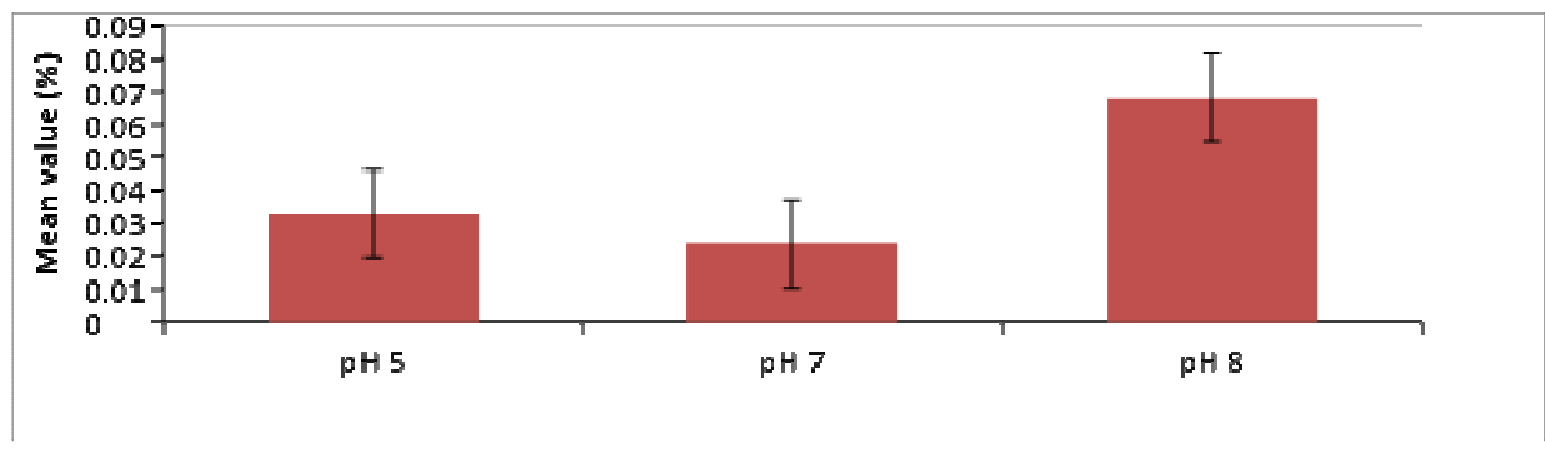

Figure 2: Effect of pH on Bioethanol Concentration

The result for GC-MS under pH5, 7 and 8 were shown in table 3. Hydrazine carboxamide and Ethyl alcohol (bioethanol) was found present in all the three $\mathrm{pH}$. At pH5 Hydrazine carboxamide and Ethyl alcohol were detected at 1.60 minutes of the analysis with a peak area of $5.76 \%$ and $1.57 \%$. These were followed by Butanoic acid and 1-Butanol at 2.24 and 2.28 minutes of the analysis with a peak area of $24.75 \%$ and $67.92 \%$. The bioethanol produced under $\mathrm{pH} 7$ shows the presence of propane, with a peak area of
$75.44 \%$ at 2.24 minutes of the analysis followed by Hydrazene carboxamide with peak area of $17.43 \%$ at 1.60 minutes and ethyl alcohol peak area of $7.12 \%$ at 1.71 minutes. While at $\mathrm{pH} 8$ Hydrazine carboxamide has a peak area of $22.37 \%$ at 1.597 minute of the analysis followed by Ethyl alcohol (ethanol) with a peak area of $13.55 \%$ at 1.706 minutes of the analysis. Isobutene was detected after 2.23 minutes of the analysis with a peak area of $64.08 \%$. 
Table 3: Gas chromatography analysis of the bioethanol produced at different $\mathrm{pH}$

\begin{tabular}{lclc}
\hline pH & Retention time (min) & Compounds & Peak area (\%) \\
\hline pH5 & 1.601 & Hydrazine carboxamide & 5.76 \\
& 1.665 & Ethyl alcohol & 1.57 \\
& 2.239 & Butanoic acid & 24.75 \\
Total & 2.786 & 1-Butanol & 67.92 \\
pH7 & 1.604 & Hydrazine carboxamide & $100 \%$ \\
& 1.706 & Ethyl alcohol & 17.43 \\
& 2.237 & Propane & 7.12 \\
Total & 1.597 & & 75.44 \\
pH8 & 1.706 & Hydrazine carboxamide & $100 \%$ \\
& 2.237 & Ethyl alcohol & 13.37 \\
& & Iso-butane & 64.08 \\
Total & & & $100 \%$ \\
\hline
\end{tabular}

\section{DISCUSSION}

Quantitative investigation revealed that $C$. schoenanthus contained several phytochemicals such as saponins, tannins, alkaloids, glycosides, steroids and flavonoids (Table1). These components are naturally occurring in most plant materials and known to possess interesting biological activity such as antioxidant, anticarcinogenic, antiviral, antibacterial, antidiabetic, anti-inflammatory (Gupta et al., 2012 and Visintini et al., 2013) which can inhibit and effect the process of fermentation activities in bioethanol production.

The presence of minerals and nutrient in the plant samples used in the analysis favours the activities of the fermentative yeast, because as a living constituent for its activity to take place there is need for some basis such as protein, carbohydrates lipids, moisture and minerals (potassium, magnesium, calcium and sodium) for the life processes and physiological activities of the yeast. This helps in the physiological activities and fermentation processes. The presence of minerals in the plant species serve as a channel for active transportation or cellular activities happening in and out of the cells because potassium, sodium and calcium serves as a transportation channel.

Grass samples used in this analysis contain high level of carbohydrates this is in line with Parameswara et al., 2010 finding on rice straw which belong to the same family compose of complex carbohydrates too. The content of carbohydrates in all the samples was high with no significant differences between the samples at $p \geq 0.05 \%$. The high content of carbohydrates shows that grasses are good source of sugars which are suitable for the production of biofuels. The amount of carbohydrates in the grass samples makes it a good source of bioethanol production. This is in line with Alessia et al., (2014) findings on the carbohydrates rich materials dispose in pineapple canneries making the waste an interesting source of bioethanol production. However, the presence of different polymeric substances (hemicellulose) on the cell wall justifies the need for pre-treatment on waste. According to Alessia et al. 2014, enzymatic activities are not affected by fermentation parameters used in his analysis. The presences of Nitrogen act as a supplements which might reduce the lag phase and increase the yeast biomass Alessia et al., 2014.

The moisture content was relatively low when compared to some grass species such as lemon grass, in camel grass this can be due to the feature of the grass species. Lemon grass requires more moisture than camel grass which is able to withstand and tolerates harsh weather conditions such as drought. The surface area of lemon grass is more than camel grass and it has a leathering covering that prevent it from losing its moisture content than camel grass. The water content of camel grass is less than lemon grass. However, when compared to moisture content of wheat $(12.3 \%)$, corn $(15 \%)$, and Barley $(11.1 \%)$ in a finding and review by Sebayang et al., 2016, that of lemon grass is close to their finding while camel grass is a little less moist. 
Ash is the inorganic matter of a fuel. In biomass fuel (biofuel), the ash content originates from biomass itself e.g materials that the plant absorbed from the water or soil collected along with the biomass. The ashing temperature of biomass is $\mathbf{5 5 0}$ degree Celsius lower than coals $\left(778{ }^{\circ} \mathrm{C}\right)$. This is because the ash contains several volatile elements collected from fossil or laboratory fuel. The ash content of herbaceous biomass is higher than that of woody biomass. Herbaceous biomass was reported to have values ranging from less than $2 \%$ up to $8-10 \%$ for rice husks. However, in waste stream the ash content may often be as high as $30-50 \%$ and is only scarcely less than $10 \%$.

The ash content is heavily dependent on the plant type and growing conditions. Ash content depend on the plant type, water uptake, inorganic sources from the environment or fertilizer used particularly with regard to some element (Potasium, Chlorine, Phosphourus) soil conditions, or part of the plants where leaves has the highest ash content. The ash content in this research is much higher (11.67\%) when compared to other species of the same family such as Sorgum $(0.4 \%)$, wheat $(1.7 \%)$, corn (1.2\%) and Barley (11.1\%) (Sebayang et al., 2016). This shows that camel grass has more fuel potential and the inorganic content is much more in camel grass too.

The percentage of protein is slightly high (11.14), though almost in same range with Kim and Day (2011) findings of protein present in wheat (12.5\%) and corn (10.2\%). Lipids and fibres are less $(3.6 \%$ and $2.83 \%$ ) in the sample of camel grass. The percentage yield of essential or volatile oil in the grass is lower. When compared to other research by Shery (2008); Health and Ageing Australian Government (2008) shows that lipid present in corn is almost in same range with lipid present in present studies, however, higher than wheat $(1.0 \%)$, Barley (1.8\%), and lemon grass $(1.83 \%)$.

Pretreatment was performed mildly to obtain high sugar yield with low inhibitor concentrations in the hydrolysates similar to a work conducted by Yinng et al., (2014). In this research the pre-treatment is performed mildly in order to obtain a high yield of bioethanol. However, to reduce the inhibitory activity of the grass samples against the yeast (S. cerevisiae) and fungi (Aspergillus niger) used for the enznymatic activities due to their antimicrobial potentials.

There are few studies that reported that Aspergillus terreus, Trichoderma spp., Cyathus stercoreus and Lentinus squarrosulus are microbes that can degrade lignocellulosic material (lignin and holocellulose) at 65-80\% and $45-75 \%$ respectively, with the pretreatment condition of $25-35^{\circ} \mathrm{C}$ for $3-22$ days Keller et al., (2003); Shide et al., (2002). In a similar study, Zheng et al., (2009) reported the effectiveness of whiterot fungi decomposing lignocellulosic biomass, in addition to enhancing the subsequent enzymatic hydrolysis. The study determined that Irpex lacteus (the employed white-rot fungi type) succeeded in degrading lignin by $43.8 \%$, and the subsequent enzymatic hydrolysis was found to be higher by 7 -fold.

Fermentation of substrates with baker's yeast is a slow process which requires some period of time to allow the fermentation process. In this research, the fermentation was allowed to stay for a period of five days in order to allow the formation of ethanol from the grass sample. According to Shinnosuke (2016), fermentation process is relatively slow, other propagation methods or content can also be employed such as mash water, enzymes and nutrient. The efficiency of the yeast during fermentation process helps in breaking pentose sugar (Glucose, Sucroose and fructose). However, room temperature is the appropriate temperature for the activity of yeast because excess heat destroys or damages the yeast.

In the analysis it was observed that $\mathrm{pH}$ has effect on the absorbance of the reducing sugar and the concentration of the bioethanol produced. However, alkaline medium has high influence on the concentration of bioethanol than neutral ( $\mathrm{pH} 7)$ and acidic (pH5) medium. The concentration of bioethanol produced decrease from $\mathrm{pH} 5$ $\mathrm{pH} 7$ while at $\mathrm{pH} 8$ the concentration increases. This indicates that $\mathrm{pH} 8$ is more suitable for the production of bioethanol. It increases as the acidity increase and also the alkalinity ( $\mathrm{pH} 5$ and 8) moving against the neutral range. 
Gas chromatography and mass spectroscopy analysis was conducted to determine the end product of bioethanol which was present in all the samples subjected to different $\mathrm{pH}$ range. Ethyl alcohol was obtained which is the main goal of the research, though other compounds where present in all the samples which is due to the presence of other organic compounds in the grass sample such as crude fibres, protein and lipids. Which in the process of fermentation and enzymatic activities hinder the formation of the following constituent: propane, butanoic acid, Hydrazine carboximide, isobutane and butanol. Interestingly most of these compound present in the end of bioethanol production have fuel potentiality. Hydrazine carboximide is found present under different $\mathrm{pH}$.

Propane is a good source of liquid gasoline that belongs to alkane group. It is a three carbon gas which is formed as a result of decomposition of organic matter over a period of time. Propane is a clean and ecofriendly gasoline commonly used in America for cooking, grilling and automobile fuel. Propane emission reaches the standard of clean air set by environment protection agency. Studies shows that, when compared to gasoline, automobile that use propane have as much as $45 \%$ less ozone forming potential (Annonymous,2017a).

Butanoic acid is a saturated short chain fatty acid found in butter, raw milk, animal fats and plant oil. In animals its formed as a result of fermentation reaction that happen within the colon of the animal species especially animals that consumes grasses during grazing as their food due to the present of carbohydrate and fibres, which is normally found in plants (Anon., 2017b).

Butanol is presences in the sample which is a four carbon alcohol just like five carbon alcohol is produced from biomass too, having low toxicity. It is considered as a potential biofuel (butanol fuel) which can be used as automobile fuel. It contains more energy at a given volume as gasoline. The use of butanol would be comparable to gasoline which can be used as an additive to diesel fuel to reduce soot emission. However it can be used as brake fluid, paint thinner and as a base for perfumes.

The presence of Hydrazine carboximide is an indication of chemical changes that happen to proximate compounds containing amino group which is found present in protein, during metabolic process by hydrolysing organism. It is also refer to as urea which is formed also as a result of reaction of ammonium with carboxylic group which are all present within the biomass of all the grass samples used in this research. From a literature reviewed hydrazine carboximide is a metabolic product of protein decomposition which is synthesized from carbon dioxide and ammonia. It is used as a synthesis in resins, fertilizers and plastics. From the analysis it was observed that the entire component found present in all the samples have fuel properties when separated. The fuel produced has an efficient fuel property.

\section{CONCLUSSION}

From the studies it was observed that bioethanol and other addition biofuel were produced from camel grass. However, subjecting the sugar source produced to pretreatment, enzymatic hydrolysis and fermentation under three different $\mathrm{pH}$ yielded bioethanol which is more in a mild alkaline $(\mathrm{pH} 8)$ this is in line with what Galadima and Okoronkwo (2011) suggestion that alkaline condition has more severe effect than the acidic condition.

\section{RECOMMENDATIONS}

The production of biofuel should be encouraged in Nigeria like other countries such as Brazil, United States of America and Australia. Developing research institution and industries for the production of biofuel would play a greater role in boosting the nation's economy, reduce over reliance on fossil fuel, tackle environmental problem, reduce rural urban migration, encourage utilization of marginalized land, improve tax revenue for the government and create job opportunity. Further research using nonagricultural food product should be explored to determine the potential of the available resources and its conservation in the environment. 


\section{REFERENCES}

Adagatin S.Y., V.S.Yaliwal, B.M. Kulkarni, G.P. Desai and N.R. Banapurmath (2015). Factors affecting Bioethanol Production from Lignicellulose Biomass (Calliandra calothyrsus), waste and biomass valorization 1. http//www.researchgate, net/publication /267816534

Alessia Tropea, David Wilson, Loredana G. La Torre, Rosario B. Lo Curto, Peter Saugman,

Peter Troy-Davies, Giacomo Dugo \& Keith W. Waldron (2014). Bioethanol Production From Pineapple Wastes, Published by Canadian Center of Science and Education, Journal of Food Research; Vol. 3, No. 4, 60-70.

Amina, R.M., Aliero, B.L. and Gumi, A.M. (2013). Phytochemical screening and oil yield of a potential herb, camel grass (Cymbopogon schoenanthusspreng.) Central European Journal of Experimental Science. 2 (3):15-19.

(http://scholarsresearchlibrary.com/arch ive.html)

Annonymous (2017a). Propane" How products are made. Encyclopedia.com: http://www.encyclopedia.com/manuactu ring/news-wires-white-papersandbooks/propane

Annonymous (2017b). Butanoic acid. En.m.wikipedia.org/wiki/butanoic

Galadima A., Z.N. Garba, B.M. Ibrahim, M.N. Almustapha, L. Leke and I.K. Adam(2011). Biofuels Production in Nigeria: The Policy and Public Opinions. Journal of Sustainable Development, 4:4: 22-31.

Galadima A. and Okoronkwo, M. U. (2011). Effect of $\mathrm{pH}$, Biogas and Biodiesel LAP Lambert Academic publisher, 26-105.

Gupta A, Naraniwal M, Kothari V. (2012). Modern extraction methods for preparation of plant extracts. International journal of Applied and Natural Sciences 1(1): 8-26.

Health and Ageing Australian Government (2008) The biology of Zea mays L. spp. mays (maize or corn), Gene Technology Regulator, 2008, 1-81.

Ying Z., Johan A.W., Bas M.M Karm M.O., Bernadein M.N., Leon C., Age K.S and Peter J.P. (2014). Identifying Inhibitory Compounds in lignocellulosic biomass hydrolysates using an exometabolomics approach. Biomed Central (BMC) Biotechnology, 14;22. http: //www.biomedcentral.com/1472$66750 / 14 / 22$

Keller F. A., J. E. Hamilton and Q. A. Nguyen (2003). Microbial pretreatment of biomass: Potential for reducing severity of thermochemical biomass pretreatment, Journal Applied Biochemistry and Biotechnology 105, 2741.

Kim, M. and D. Day (2011). Composition of sugar cane, energy cane, and sweet sorghum suitable for ethanol production at Louisiana sugar mills, Journal of Industrial Microbiology and Biotechnology, 38, 803-807.

Musa A.R. (2011). Phytochemical Screening and Insecticidal Potential of Cymbopogon citratus and Cymbopogon schoenanthus. Unpublished M. Sc. thesis Usmanu Danfodiyo University, Sokoto, Nigeria.

Parameswaran B., R.Sindhu, R.R., Singhania, S.Vikram, L. Devi, S. Naglakshmi, N. Kurien, R.K.. Sukumaran, A. Pandy (2010). Bioethanol Production from Rice Straw: An Overview Bioresource Technology. 10,4767-4774. www.researchgate.net/publication/4003 7746

Sebayang A. H., H. H. Masjuki, Hwai Chyuan Ong, S. Dharma, A. S. Silitonga, T. M. I. Mahlia and H. B. Aditiyac (2016).A perspective on bioethanol production from biomass as alternative fuel for spark ignition engine. Journal Royal Society of Chemistry. www.rsc.org/advances 6, 14964-14992.

Shewry P. R. (2008). Wheat, J. Exp. Bot., 2009, 60, 1537-1553.

Shinnosuke, O., Jacek A. K., William S.J., L. Cai, S. Rice and J. Van Leeuwen (2015). Optimization of extraction parameters for quantification of fermentation volatile by products in industrial ethanol with solid phase microextraction and gas chromatography, Journal of the institute of Brewing, volume 122, issue 1,2016, pages: 102-109.

Shide E. G., P. A. Wuyep and A. Nok (2002). Studies on the degradation of wood sawdust by Lentinuss quarrosulus (Mont.) singer, African Journal of Biotechnology, 3, 395-398.

Visintini Jaime MF, Redko F, Muschietti LV, Campos RH, Martino VS, Cavallaro LV. (2013). In vitro antiviral activity of plant extracts from Asteraceae medicinal plants. Virology Journal, 10: 245

Zheng Y., Z. Pan and R. Zhang (2009). Overview of biomass pretreatment for cellulosic ethanol production, International Journal of Agricultural Biological Engineering, 2, 51-68. 